\title{
SUBSISTÊNCIA E CLIMA NA ADAPTAÇÃO DOS ABORÍGENES DA TERRA DO FOGO
}

A Terra do Fogo, a porção mais austral das Américas, foi colonizada por grupos caçadorescoletores no começo do Holoceno. Os sítios arqueológicos mais antigos datam de aproximadamente 12.00 anos atrás (Clapperton 1992). Ao longo dos milênios, estes caçadores-coletores (carnívoros nômades) se diferenciaram em quatro populações lingüística e culturalmente diversas (Selknam, Haush, Yaghanes e Alakalufes), que também podem ser distinguidas de acordo com seu modo de subsistência, associado, por sua vez, à sua distribuição geográfica (Tabela 1).

Morfologicamente, os aborígenes da Terra do Fogo se caracterizam pelo seu tamanho e robustez. No crânio, esta se expressa através da elevada incidência de sujperestruturas (por exemplo, tubérculos e torus), como também por um desenvolvimento pronunciado da musculatura ligada à mastigação (principalmente os músculos temporal e masseter). Entretanto, é o tamanho dos arcos superciliares e a freqüência da quilha sagital que diferenciam estas populações de outros povos da Terra (Lahr 1995).

Semelhanças entre Fueguinos e Esquimós por um lado, e Fueguinos e aborígenes Australianos por outro, já foram observadas anteriormente. Fueguinos e aborígenes Australianos apresentam níveis semelhantes de robustez. Ambos grupos possuem arcos superciliares muito pronunciados, assim como freqüências altas de quilha sagital e torus occipital. No entanto, estas características de robustez, que também ocorrem em populações mo- dernas ancestrais, não são indicadoras de proximidade filogenética. Elas podem ser interpretadas como retenções morfológicas ou plesiomorfias. Fueguinos e Esquimos (Fig. 1), por outro lado, apresentam um desenvolvimento similar da musculatura mastigatória, que através de seus efeitos biomecânicos sobre a forma do rosto e do crânio, geram semelhanças morfológicas. Estas semelhanças representam uma convergência relacionada ao uso acentuado da musculatura mastigatória (estresse mastigatório), tanto para a trituração de alimentos como através do uso dos dentes como ferramentas (atividade para-mastigatória). Portanto, as peculiaridades observadas na morfologia craniana Fueguina devem ser interpretadas como decorrentes de processos adaptativos únicos, resultantes da interação complexa entre a manutenção de níveis Pleistocênicos de robustez e o efeito do estresse mastigatório sobre o crânio. Na presente nota discutiremos um dos aspectos desta morfologia, ou seja, a relação entre o grau de desenvolvimento dos músculos temporais, a frequiência da quilha sagital e o padrão de desgaste dentário.

A relação funcional entre quilha sagital e tamanho da musculatura temporal foi proposta por diversos autores (Hrdlicka 1910, Hylander 1977, Lahr 1995). De acordo com estes estudos, a quilha sagital, uma peculiaridade quase exclusiva de povos Feuguinos, Esquimós e Australianos, é interpretada como um reforço arquitetônico do crânio decorrente dos efeitos do estresse mastigatório (Hylander 1977). No entanto, ainda não ficou estabe-

TABELA 1

Subsistência e ecologia dos aborígenes da Terra do Fogo

\begin{tabular}{|c|c|c|c|c|}
\hline Povos & Região & Índice Pluviométrico & Geo/Vegetação & Subsistência \\
\hline $\begin{array}{l}\text { Selknam, Haush } \\
\text { (caçadores-coletores) }\end{array}$ & atual Argentina & baixo & $\begin{array}{l}\text { estepes temperadas } \\
\text { semidesérticas }\end{array}$ & $\begin{array}{l}\text { tuco-tuco (roedor) } \\
\text { e guanaco }\end{array}$ \\
\hline $\begin{array}{l}\text { Yahgan, Alakaluf } \\
\text { (canoeiros-pescadores) }\end{array}$ & atual Chile & alto & $\begin{array}{l}\text { florestas densas, } \\
\text { canais marítimos } \\
\text { e ilhas }\end{array}$ & $\begin{array}{l}\text { moluscos, aves e } \\
\text { mamíferos marí- } \\
\text { timos }\end{array}$ \\
\hline
\end{tabular}



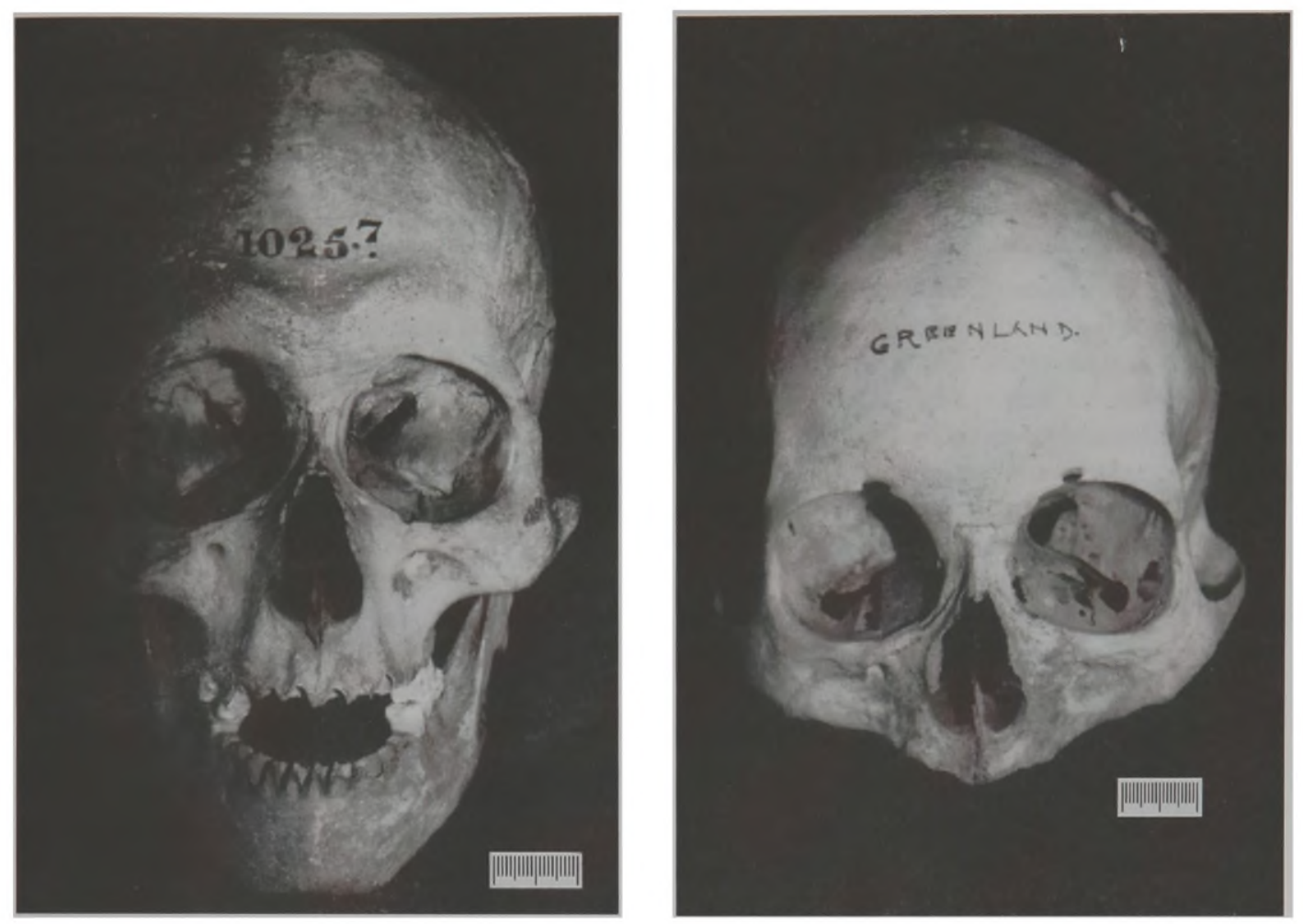

Fig. I - Semelhanças entre um crânio Fueguino (esquerda) e um Esquimó (direita).

lecido se a sua formação resulta de processos mecânicos ao longo da vida dos indivíduos (processos ontogenéticos) ou de processos adaptativos da população a longo prazo. Uma maneira de se abordar este problema é estudar a relação deste complexo quilha-musculatura com um indicador de estresse mastigatório puramente ontogenético, como o desgaste dentário.

Um estudo preliminar de dezesseis crânios Fueguinos alojados no Museu de História Natural de Londres, revelou que $56 \%$ dos dentes apresentam desgaste muito pronunciado, no qual o esmalte dentário na superfície oclusal se encontra ausente ou reduzido a um perímetro muito fino. Além disso, o plano de desgaste é horizontal, expondo, em muitos casos, a dentina secundária. O músculo temporal de treze destes indivíduos mede $97,2 \mathrm{~mm}$ de altura e $149,9 \mathrm{~mm}$ de comprimento em média, o que representa um tamanho 6 a $18 \%$ maior do que aquele observado em crânios de diversas populações da Terra, como Europeus, Africanos, Asiáticos e Australianos.
Uma exceção são os Esquimós que, como mencionado acima, também apresentam um desenvolvimento pronunciado desta musculatura, com $100,1 \mathrm{~mm}$ de altura e $154,9 \mathrm{~mm}$ de comprimento, em média. Além disso, entre os treze crânios Fueguinos, $77 \%$ apresentam quilha sagital.

Para examinar a relação entre as dimensões da musculatura temporal e o grau de desgaste dentário, este último foi classificado em duas categorias: moderado e acentuado. Por causa do tamanho da amostra, foi realizada uma análise estatística não-paramétrica (Kruskal Wallis), que revelou o grau de desgaste não estar relacionado ao tamanho da musculatura. No entanto, a presença de desgaste acentuado na dentição anterior (incisivos e caninos) está significativamente relacionada ao maior comprimento do músculo temporal (sendo que tal relação não se observa com o desgaste dos dentes posteriores, os molares). Estes resultados indicam a existência de uma relação biomecânica entre o desgaste da dentição anterior e o desenvolvimento longitudinal da musculatura 
temporal durante a vida do indivíduo. No que diz respeito à função da dentição ánterior, sabe-se que esta participa apenas marginalmente no processo de trituração dos alimentos. Por outro lado, evidências etnográficas revelam que os dentes incisivos eram usados na produção de artigos como cordas e vestimentas, assim como para segurar diversos implementos (como flechas) durante diferentes atividades (como a caça). Portanto, sugere-se que estas atividades para-mastigatórias teriam representado causas importantes tanto do desgaste da dentição anterior como do desenvolvimento muscular ocorrido durante a vida.

Este processo ontogenético explica parte da morfologia observada nos Fueguinos. No entanto, a falta de relação entre o grau de desgaste dentário e as dimensões musculares, assim como a alta fre- quiência de quilha sagital na amostra, indicam um componente genético. Outros estudos, como os de Ossenberg et al. (1995) em Esquimós, mostraram resultados semelhantes, interpretados como a ação de um processo adaptativo a longo prazo favorecendo aqueles indivíduos que melhor respondem às pressões decorrentes do estresse mastigatório em vida. Desta maneira, o fenótipo destas populações pode ser interpretado como resultante da sobreposição de processos seletivos a curto e longo prazo que levaram a uma adaptação complexa, evidenciando uma combinação única de variáveis relacionadas a tamanho e robustez.

\section{Sabine Eggers* Marta Mirazón Lahr*}

\section{Referências bibliográficas}

\author{
CLAPPERTON, C.M. \\ 1992 La ultima glaciación e deglaciación en el Es- \\ trecho de Magallanes: Implicaciones para el po- \\ blamiento de Tierra del Fuego. Ans Inst Pat \\ Ser Cs Hs, 21:113-128.

\section{HYLANDER, W.L.} \\ 1977 The adaptive significance of Eskimo craniofacial \\ morphology. In A.A. Dahlenberg; T.M. Graber \\ (Eds.) Orofacial growth and development. The \\ HRDLICKA, A. \\ Hague: Mouton: 129-169. \\ 1910 Contribution to the anthropology of Central \\ and Smith Sound Eskimo. Anthropological \\ papers of the American Museum of Natural \\ History, 5: 177-280.
}

Recebido para publicação em 10 de outubro de 1997.

\section{LAHR, M.M.}

1995 Patterns of Modern Human Diversification: Implications for Amerindian Origins. Yearbook Phys Anthrop, 38:163-198.

OSSENBERG, N.S.; STEELE, S.S.; HOWES, J.

1995 Occlusal load and temporomandibular reaction forces in prehistoric eskimos versus modern Eurasians: a comparison based on three dimensional analysis of static equilibrium from craniofacial measurements. Paper presented at the 1995 AAPA annual meeting, March 28- April 1, Oakland, California.
(*) Departamento de Biologia, Instituto de Biociências da Universidade de São Paulo. 